\title{
Innovation through Tradition in Design-Intensive Family Firms
}

Stefano Magistretti ${ }^{1}$, Claudio Dell'Era ${ }^{1}$, Federico Frattini ${ }^{1}$ Antonio Messeni Petruzzelli ${ }^{2}$ ${ }^{1}$ School of Management, Politecnico di Milano - Piazza L. da Vinci, 3220133 Milano Italy ${ }^{2}$ Department of Mechanics, Mathematics and Management, Politecnico di Bari, Bari, Italy

This is a post-peer-review, pre-copyedit version of an article published in Journal of Knowledge Management. The final authenticated version is available online at: https://doi.org/10.1108/JKM-07-2019-0399

Please cite as: Magistretti, S., Dell'Era, C., Frattini, F. and Messeni Petruzzelli, A. (2020), "Innovation through tradition in design-intensive family firms", Journal of Knowledge Management, Vol. 24 No. 4, pp. 823-839. https://doi.org/10.1108/JKM-07-2019-0399

\begin{abstract}
Purpose - Several studies show that identity is a critical success factor in design intensive industries, leading managers and executives to identify solutions that enable firms to simultaneously innovate while preserving their link with the past. Accordingly, scholars have recently revealed the role of the so-called innovation through tradition strategy. However, despite the relevance of this strategy, how design-intensive firms may exploit knowledge pertaining to the past is still unclear.
\end{abstract}

Design/methodology/approach - The research contributes to this line of inquiry by conducting a longitudinal analysis of two leading Italian design-intensive firms, B\&B Italia and Cassina. Specifically, through almost 30 hours of interviews with 11 key informants and the analysis of various secondary sources, a unique database of over 900 products covering the period of 1960-2016 was developed.

Findings - Our findings reveal that both firms leverage knowledge from the past mainly to preserve firm identity, as indicated by the two indicators employed to capture the use of knowledge pertaining to the past (i.e., design tradition intensity and design tradition depth). In addition, the study shows that the values of these indicators significantly increase when ownership control shifts from family-based to fund-based.

Originality/value - The paper looks at design artifacts as a source of knowledge, exploring how they can support firms in reinforcing their identity. The original contribution to the design 
through tradition literature is in unveiling the product signs dimension of this particular innovation strategy.

Keywords: Design; Family Firm, Innovation, Open Innovation, Innovation through tradition Paper type: Research Paper

\section{Introduction}

Design is acknowledged as a strategic source of competitive advantage (Capaldo, 2007). As such, academic research has increasingly looked into the interplay between design and innovation strategies (Brown, 2008; Verganti, 2009), and how such interplay can be managed to produce enduring competitive advantage (Magistretti and Dell'Era, 2019). Moreover, scholars have outlined that design can help companies envision innovative scenarios and new products (Ravasi and Lojacono, 2005), and may also offer the unique opportunity to link novel solutions and approaches with historical artifacts, hence strengthening the company's identity (Karjalainen and Snelders, 2010).

Recent literature contributions have dispelled the myth that sees tradition and innovation as opposed, supporting instead the fundamental importance of tradition for the success of innovation (Messeni Petruzzelli and Savino, 2015; De Massis et al., 2016a; Manfredi Latilla et al., 2018; Presenza et al., 2019). In fact, thanks to past knowledge interiorization and reinterpretation capabilities, firms are able to release the potential advantages of tradition in terms of value creation and capture (Keen and Tan, 2007). Recent research has shown that design firms may benefit from leveraging historical resources, since these can be a source of innovation and allow maintaining a link with the past (De Massis et al., 2016a), thus contributing to create a unique and distinctive identity. In addition, the concept of ownership in the family business become more relevant when the focus is on innovation through tradition 
(Sasaki et al., 2019). Indeed, family ownership is a factor that provides continuity, and is usually associated with a long-lasting relationship with external partners (Magistretti et al., 2019) and stronger ties with past sources of knowledge (Capaldo, 2007; De Massis et al., 2016a). Along this direction, design is found to play a crucial role in favoring the use of knowledge from the past because it helps consolidate a firm's identity, which is in turn a critical success factor in design-intensive industries (Dell'Era and Verganti, 2007; Micheli and Gemser, 2016). In the design field, the knowledge management system, is usually defined as design knowledge (Åman, Andersson and Hobday, 2017). Design knowledge is the process of both passively integrating knowledge in products and actively creating new knowledge by crafting new products (Simon, 2019). This shows how design knowledge is the act of both integration of design knowledge and the generation of new knowledge which is labeled as integration by design in the literature ( $\mathrm{man}$, Andersson and Hobday, 2017). This field has been studied to understand how companies can integrate design knowledge systems in design process to better support the integration of multiple perspectives (Tiwana and Ramesh, 2001) as well as on how design knowledge can be built by understanding information about both the product and the processes from the past (Zha and Sriram, 2006). However, this line of research has produced conflicting findings, as the implications of using knowledge pertaining to the past is strongly dependent on a number of specific contingencies, hence turning from a cause of inertia (Sørensen and Stuart, 2000) to a source of innovation (Capaldo et al., 2017; Ardito et al., 2018). Moreover, recent research points out that design-intensive firms can manage collaborative innovation differently when they involve external designers (Magistretti et al., 2019). Nevertheless, some gaps remain in current knowledge. First, how design-intensive firms strategically tap into and use knowledge pertaining to the past to innovate is still unclear, hence calling for further theoretical and empirical research. Second, what is the impact of the knowledge pertaining to the past on the design knowledge and how it might impact the 
definition, the creation, and the maintenance of the design knowledge system is still vague. Third, to what extent is the innovation through tradition strategy valid in various contexts and industries? Is it market-specific or culturally dependent? Moreover, some studies attempt to shed light on knowledge from the past related to collaborations (e.g., designers; Simoni et al., 2019 Magistretti et al., 2019), but less is known on the codified source of knowledge (e.g., raw materials, product signs, and manufacturing processes). Thus, this study attempts to understand how design-intensive firms use knowledge pertaining to the past to innovate, in particular, by looking at the artifacts (e.g., products signs) dimension of the form of past knowledge.

This paper relies on two leading design-intensive companies that operate in the furniture industry: B\&B Italia and Cassina. Their over 50-year long history provides paradigmatic examples of design-intensive firms that constantly face the problem of designing new products that reinforce their identity. In this study, we created and adopted two different indicators to capture how design-intensive firms use knowledge pertaining to the past to innovate: design tradition intensity and design tradition depth. The former indicates to what extent a company recalls products from its history. The latter indicates how far back in time the products belonging to a determined set of traditional product groups are anchored in their past. Our study shows that the values of tradition intensity and tradition depth significantly increase when ownership control shifts from family-based to fund-based, highlighting that the fund-based control leverages knowledge from the past to counterbalance the absence of the founding family. This is e relevant insight for knowledge management, family firms, and innovation literature because it shows how the family conditions influence the design knowledge actively created or passively integrated in innovative products.

In so doing, our study contributes to both the academic and practitioner debates. For academics, the study enriches current knowledge by proposing two indicators that might be used to conduct investigations on design, innovation through tradition, and knowledge management. Indeed, 
by discussing how companies can master the usage of design tradition intensity and depth the paper enriches the understanding of the inner mechanism on how to leverage the knowledge of the past. Moreover, it enhances understanding on the innovation through tradition model by shedding light on possible measures of product signs knowledge from the past. In terms of practitioner contributions, our study shows that knowledge from the past, related to tangible products, can be mastered by companies to spread innovation through tradition. The two intensity and depth indicators can be considered proxies of a potential strategy that firms can put in place to control knowledge from the past in their product design.

\section{Theoretical Background}

In the following, we first summarize the main contributions regarding product design and identity. Then, we explore the literature on tradition and its relationship with innovation in knowledge management.

\subsection{Product design and identity}

In today's business and academic arenas, design is increasingly viewed as an important strategic resource. Indeed, the last couple of years have seen a real explosion in business and research literature where scholars and companies alike attempt to continuously link design to innovation and business strategy. A series of case studies shows that companies can apply design to get closer to users and better understand their needs. The successes of major design firms such as IDEO (Kelley, 2001) or Continuum (Lojacono and Zaccai, 2004) foresee that product development should start from a deep analysis of user needs. This illustrates how central design is to business today, and how the influence of design is growing beyond the tech industry into the corporate world at large. The ability to manage this two side of the innovation, user needs and technology, is recognized as one of the difficulties in design knowledge literature (Dalpiaz, Rindova, Ravasi, 2010; Åman, Andersson and Hobday, 2017). Indeed, 
being able to leverage design as both a method to integrate existing knowledge in products and create new knowledge has been studied (Leonard-Barton and Sensiper, 1998, Tiwana and Ramesh, 2001).

As design is recognized as a strategic resource, many scholars also investigate the link between design, innovation, and competitive advantage (Platt et al., 2001; Borja de Mozota, 2004; Boland and Collopy, 2004; Veryzer, 2005; Dell'Era and Verganti, 2011). Several studies (Dumaine, 1991; Schmitt and Simonson, 1997) demonstrate that consumers increasingly make brand choices based on the aesthetic and symbolic value of products and services. Consequently, companies invest a large amount of resources in developing new designs for their products in order to make them more fashionable rather than more functional (Pesendorfer, 1995; Cappetta et al., 2006). Postrel (2003) has underlined the role of the "look and feel" of people, places, and things, demonstrating that the aesthetic and symbolic dimensions of a product are increasingly relevant in many different industries. This is usually a type of design knowledge more passive and less useful to identify new meaningful product (Åman, Andersson and Hobday, 2017).

Recognition is particularly relevant in design-intensive industries where competitive advantage cannot be pursued through products with superior technical performance. Companies can adopt several means to increase the recognition of their products in the market (Magistretti et al., 2019). Design is one of the main vehicles adopted to convey the firm's identity and tradition as a main ingredient of fostering a strong visual identity for a brand and creating brand value (Schmitt and Simonson, 1997; Stompff, 2003; Borja de Mozota, 2004). Indeed, in the design field, much attention has been paid to the role of designers in mediating and brokering different sources of knowledge (Dell'Era and Verganti, 2010). Design has been defined as a powerful way to create a link among different players in the innovation and creation of product design (Walsh, 1996). Especially in industries where product identity is crucial, firms have to manage 
the delicate trade-off between launching innovative products and maintaining their product identity (Micheli and Gemser, 2016; Dell'Era et al., 2018). Recent research has shown that the appropriate integration of design resources in new product development can positively influence innovation performance and brand identity (Beverland, 2005; Ravasi and Stigliani, 2012). Investigating the Nokia and Volvo cases, Karjalainen and Snelders (2010) show that design elements can act as the main vehicle of brand value creation, allowing firms to convey consistent messages and enhance the identity of their product portfolio (Crane, 2012). Product identity is a fundamental lever to increase company recognition and brand awareness, and differentiate a firm's offerings from its competitors (Brode et al., 2014). In this direction, the study on the Serie7 chair is inspirational, highlighting the role that design can play in reinterpreting existing knowledge and increasing company recognition and brand awareness through product signs (Gasparin and Green, 2018). In this regard, designers can significantly contribute to developing product signs that convey consistent messages to customers (McCormack and Cagan, 2004; Trabucchi et al., 2017). Moreover, recent studies show that renewal and identity are two major drivers of collaboration for design-intensive family firms that leverage collaborative innovation (Magistretti et al., 2019).

\subsection{Tradition and innovation in knowledge management}

According to conventional innovation thinking, traditional knowledge is deemed a threat to the effectiveness of innovation, as it can lead to path dependency, inflexibility, conservatism, inertia, and core rigidity (Leonard-Barton, 1992; Sørensen and Stuart, 2000). This assumption, known as "recency bias", sees the past as an obstacle, a source of resistance that can reduce innovation potential and prevent meeting current environmental needs. Instead, recent studies support the hypothesis that past knowledge is a valuable competitive advantage and provides a great and powerful opportunity to successfully innovate (e.g., Carillo, 1997; Messeni Petruzzelli et al., 2012; Capaldo et al., 2017; Ardito et al., 2018; Presenza et al., 2019). The 
key path to reach this innovation advantage lies in the way a firm leverages its past knowledge, meaning how it accesses, uses (knowledge search process), interiorizes, reinterprets (recombination process) and transfer temporally distant knowledge (Gurteen, 1998; Swan et al., 1999). De Massis et al. (2016a) define tradition as the "temporal knowledge, competencies, materials, manufacturing processes, signs, values, and beliefs pertaining to the past. Tradition involves accumulation of know-how, symbolic and cultural content and micro-institutions of practice handed down across generations and contributing to shaping the identity of individuals, organizations and territories". The literature clearly shows that this aspect is of primary relevance when the focus is on family firms (Chrisman et al., 2015). Indeed, family business scholars have studied the transfer of knowledge across generations and as a result of organizational changes (e.g., Sasaki et al., 2019). Moreover, according to De Massis et al. (2016a) innovation can be achieved through tradition (see Figure 1).

The first of the two dynamic capabilities in the model is interiorization, defined as the “assimilation and sharing of knowledge related to the firm's traditions or its territory traditions across the organization" (De Massis et al., 2016a, 97). In literature this concept has been discussed in the terms of knowledge translation in innovation processes, especially in the role that artifacts such as prototypes might have in boosting open innovation (Simeone, Secundo, Schiuma, 2017). The second is reinterpretation, described as the "combination of elements of past knowledge with elements of novel knowledge/technologies in order to pursue product innovation" (De Massis et al., 2016a, 103). The first phase of the process outlined in the model is the identification of resources, namely, the sub-process in charge of recognizing and collecting the sources of past knowledge through temporal search activities. There are two types of sources from which the firm can glean past knowledge: the tradition of the firm and the tradition of its territory. During the interiorization process, raw past knowledge is elaborated and refined. The outcome of this phase can be forms of codified and/or tacit past 
knowledge. During the reinterpretation process, tacit and/or codified knowledge is combined with novel knowledge/technologies to develop product innovation. The outcome can be new functionalities and/or new meanings. This process is just one of the contributions existing in the knowledge creation literature where different investigations have been performed on how knowledge is created (Jeffery, 2005; Hibbert and Huxham, 2011).

(Insert Figure 1 about here)

\section{Research Methodology}

\subsection{Conceptual framework}

Emerging from the literature is that a proper measure of the use of tradition in the innovation process is lacking. To address this, we developed a conceptual framework incorporating the relation between the different constructs: (i) tradition, (ii) new product development, and (iii) family ownership. Indeed, the model proposed in Figure 1 and the different elements illustrate that types of past knowledge, in the form of products signs, can be measured with the two indicators: design tradition intensity and design tradition depth. Moreover, the aim of the framework is to show how these two indicators are related and might explain the underpinning strategies of different product designs. In addition, given our aim of understanding how changes in ownership might impact this, we introduce another two variables: control and generation. This proposed framework guided us in gathering the data and investigating the relations among the different dimensions in our sample of firms.

\subsection{Selection of cases}

Considering the exploratory nature of our study on how design-intensive firms use knowledge pertaining to the past to innovate, a case study methodology appeared to be the most suitable (Yin, 2011). Applying theoretical and convenience sampling, we selected two design-intensive firms with over 50-year long histories (i.e., B\&B Italia and Cassina SpA; see Table 1), in accordance with Siggelkow's (2007) guidelines on the selection of inspiring cases. Indeed, the 
two firms are considered worldwide as paradigmatic of design-intensive firms, constantly facing the problem of designing new products to strengthen their identity, and have been bestowed the prestigious Compasso d'Oro award by ADI (Italian Design Association). Moreover, they belong to the same geographic area, which is relevant to our study, as contextual factors often influence tradition and innovation. Furthermore, we aim to understand how this type of firm manages knowledge, highly relevant for family business researchers and practitioners. Indeed, family businesses are considered the most appropriate to investigate how the past can be leveraged in product innovation thanks to their longevity and ability to create links between their past, present, and future (De Massis et al., 2016b). The types and traits of family businesses can vary greatly, but they all share a common feature, namely, the business is shaped by the vision of a dominant coalition controlled by the members of the same family (Kammerlander et al., 2015). Family businesses may thus benefit from favored access to past knowledge and leverage their own tradition to create innovation. Indeed, family business scholars highlight the ability and willingness paradox in family firm innovation (Chrisman et al., 2015). Thus, selecting two companies that have faced both family and fund ownership control may also shed light on this important paradox.

(Insert Table 1 about here)

\subsection{Data collection}

We used primary and secondary sources to collect our data. We conducted 11 in-depth interviews between January and May 2015 with an average duration of approximately three hours, which were recorded and then transcribed. In choosing the informants, we paid particular attention to the need to cover the entire history of the two firms, hence interviewing both former and current employees. In particular, our informants were managers and employees highly involved in the research and development (R\&D) department, as in designintensive firms, $R \& D$ is the business unit most dedicated to innovation (see Table 2). 
(Insert Table 2 about here)

Data were also collected from secondary sources including official websites, in-store visits, catalogue collections, and books, specifically, 'Un'Industria per il Design' [An Industry for Design] for B\&B Italia, and 'Made in Cassina' for Cassina SpA. Both books contain all the products developed by each $R \& D$ department over their history. Integrating the information provided by the firms with the data collected from secondary sources allowed us to create a unique and longitudinal database, a sort of chronology of the firms in terms of covering their entire history, products launched, and collaborations with designers. The database includes more than 927 products over the period 1960-2016 (399 for B\&B Italia, and over 528 for Cassina).

\subsection{Data operationalization}

To analyze how these firms, recall their tradition, we needed to identify the products that belonged to the tradition asset of each firm. In particular, products create a part of tradition when they recall past products that have similar features. We categorized products that had the same common features into groups called design paths. A design path is defined as a set of products launched with common stylistic, visual, functional, and meaning elements (see Figure 2). These products are characterized by the fact that they directly or indirectly refer to a common design ancestor (i.e., the first product with those particular traits that characterize the design path). In turn, successive products confer a contribution that enriches and redefines the DNA of the design path over time. Thus, the requirement for inclusion in a design path is the product's placement on the line that links the products over time. All the lines that can be identified represent the firm's tradition.

(Insert Figure 2 about here) 
After creating the design paths, we needed validation from a panel of experts. In particular, we sought the opinions of professionals in the design furniture sector. The selection criteria for experts were: (i) over ten years' experience in one of the two companies; (ii) more than 15 years in the furniture sector; (iii) job roles in new product development or related. This led to selecting two from B\&B Italia and two from Cassina Spa who have broader knowledge of the overall furniture sector, significant experience in new product development, and lengthy careers in the firms.

In total, the experts' validation allowed us to identify 36 design paths (20 for B\&B Italia and 16 for Cassina Spa) composed of 194 traditional products (115 developed by B\&B Italia and 79 by Cassina Spa).

As previously mentioned, we measured two indicators to capture the strategies the companies adopted in using knowledge pertaining to the past. Design tradition intensity indicates how much a company leverages its own tradition, that is to say, the extent to which it recalls products from its past history. Design tradition intensity is defined as the ratio of the total number of products belonging to design paths launched on the market in a certain period of time over the total number of products launched on the market in the same period of time:

$$
\operatorname{DTI}_{t}=\frac{d t p_{t}}{p_{t}}[\%]
$$

$D T I_{t}=$ Design tradition intensity at time $t$

$d t p_{t}=$ Total number of design tradition products (products belonging to design paths) launched on the market at time $t$

$p_{t}=$ Total number of products launched on the market at time $t$

$t=$ Period of analysis

Design tradition depth indicates the seniority of each design tradition product, showing how far back in time the products belonging to design paths are anchored. The seniority of a design tradition product is computed in relation to the position in its design path. However, this 
indicator does not only show the absolute seniority of the design tradition product in comparison to its design ancestor, but also takes into consideration the temporal distribution of other design tradition products presents in the design path up to that time. Thus, not only considering the difference between the year of release of the design tradition product and the year of release of its design ancestor, but also all the other differences between the year of release of the design tradition product and the years of release of all the other design tradition products present in that path up to that time. The reason for this lies in the fact that a design tradition product equally recalls all the design tradition products that preceded it in its design path. Therefore, design tradition depth is defined as the mean of the differences between the release year of a design tradition product and the years in which the previous products, belonging to the same design path, were launched on the market:

$$
D T D_{d t p}=\sum_{i=1}^{k-1} \frac{T_{k}-T_{i}}{k-1}[t]
$$

$D T D_{d t p}=$ Design tradition depth related to the design tradition product

$i=$ Index of the position of a design tradition product in the design path

$k=$ Position of the design tradition product (on which DTD $D_{d p}$ is calculated) in the design path

$T_{i}=$ Year of release of the design tradition product $i$

$T_{k}=$ Year of the release of the design tradition product (on which DTD dtp is calculated)

\section{Empirical Results}

Several events over the history of a company can challenge its identity. Even if tradition can be conceived as a cumulative asset that can be exploited over the firm's history, the growth of this cumulative asset can be "interrupted" by pivotal events (such as succession, changes in ownership, brand repositioning, paradigm shifts in the industry, etc.) that may make tradition more or less "exploitable" to renew its identity. To investigate how the product strategy based on the use of knowledge from the past can change over time, we identified specific pivotal 
changes in ownership that challenged the identity. In particular, as reported in the literature, when the focus is on family firms, one of the most significant changes is generational succession and change in ownership control from a family to a fund (De Massis et al., 2008; Magistretti et al., 2019). Moreover, these changes affect innovation and especially the creation of the cumulative asset that is tradition (De Massis et al., 2016a). Thus, the two changes considered are: control, indicating the entity that financially owns the firm, which may be the family or a fund; generation, indicating the generation of the family that manages the firm.

\subsection{B\&B Italia: Within case analysis}

Analyzing ownership control of B\&B Italia over its history, we identified three different periods. The first began in 1966, when the company was born, and spans to 2002. In the following year, due to concerns of the company's continuity, the Busnelli family accepted the offer of a private fund. For the remaining years, the owner of the company was first Opera Fund, and then Investindustrial, two venture capital companies. Despite this, the family remained present in the company, and in 2013, the third generation of the Busnelli family entered B\&B Italia (see Figure 3).

Over its history, B\&B Italia has been led by three generations of the Busnelli family. From 1966 to 1987, Piero Ambrogio Busnelli was the president of the company, and the only member of the Busnelli family until 1988 when his three sons Giorgio, Giancarlo, and Emanuele joined the company (2nd generation). They maintained a leading position until 2014, despite the acquisition from the private equity fund. The last period began in 2014, when the third generation entered with leading position in B\&B Italia (see Figure 3).

(Insert Figure 3 about here) 
Thanks to the extensive use of tradition, we identified 20 different design paths composed of 112 products. Each design path has an average number of 5.6 products. Several design paths show ancestor products that can be considered icons that clearly define the company's identity. For example, design path \#17 is composed of five products: it started in 1970, and its last product was produced in 2015 (see Figure 4). Analyzing the Tufty-Time sofa designed by Patricia Urquiola revealed a clear the return to the past, or going back to the modularity of Camaleonda, with the intent of creating a youthful system with free and versatile configurations. All the products in this design path started with a pouf, the basic element that can be recombined with other elements, such as armrests, or standard or double depth. All these elements create the possible configurations of conventional sofas or island systems according to consumer preferences, as the quotes below reports.

“...When we interacted with Urquiola to start the discussion that would have brought to the creation of the Tufty-Time 15, we aimed at leveraging a tradition of a modular system of upholstering where the cube was central. Thus, the final design played with this simple unit by giving birth to a combinable sofa..." B\&B Italia, Global Communications Director

Analyzing the aesthetic of the products, the leather or fabric covers of these sofas are divided into large squares, joined by a bottom fold. Moreover, all these products have a common meaning: the sofa becomes a meeting place, a comfortable refuge to relax. To sum up this design path, the keywords are softness and compositional freedom.

(Insert Figure 4 about here)

\subsection{Cassina SpA: Within case analysis}

From 1960 to 1989 , control of Cassina SpA was characterized by the presence of a family member. In fact, in this period, the owner was a member of the Cassina family. In 1990, due 
to leadership concerns and conflicts, a private equity fund, Strafor Facom, acquired Cassina SpA, even though the family maintained an important role in the firm (see Figure 5).

From 1927 to 1973, the leaders of the company were Cesare and Umbero Cassina, the founders. In 1974, Franco Cassina and Rodrigo Rodriguez joined the company; they were members of the extended family. Therefore, from 1974 to 1989 , the leading role in the company was covered by the 2 nd generation of the Cassina family. In 1990, to resolve problems in conducting the company, it was sold to Strafor Facom, a private equity fund. This change of ownership also coincided with the entry of the 3 rd generation. This period ended in 2005 because in the following year, Charme Investments acquired $100 \%$ of Cassina SpA. This date coincided with reducing the role of the 3rd generation in the company. To assess the design tradition indicators, we did not consider the family founder phase (from 1927 to 1960), since the company had not really been a design intensive firm in this period (Magistretti et al., 2019) (Figure 5).

(Insert Figure 5 about here)

Tradition is one of the core principles of Cassina SpA. For this reason, we were able to identify 16 different design paths, characterized by the presence of 79 traditional products. The design paths are composed on average of 4.94 products. For example, design path \#14 is composed of four traditional products conceived by different designers (see Figure 6). The Maralunga sofa was a breakthrough in the furniture industry thanks to the adjustable backrest. This new functionality resulted in the sofa winning a Compasso D'Oro award in 1979. Thanks to its outstanding designer Vico Magistretti, many other designers brought this element into the innovation process and created new design tradition products. In fact, all the products in this design path had a part that could be folded or adjusted to create more comfort. In particular, the Maralunga and Sled sofas had a reclining backrest, the chaise longue Wink had an 
adjustable footrest, and the armchair Hal had both an armrest and backrest with automated movement.

“... hidden mechanism is one of the key traits of Cassina. This is the reason that brings the company year over year to propose armchairs and sofas that have a foldable part. This because Cassina is well known for craftsmanship in woodworking, but it is also famous for the ability to combine different technologies. For example, Maralunga mechanisms are the same as the bike..." Cassina, R\&D Director

(Insert Figure 6 about here)

\subsection{Cross-case analysis}

The within case study results show that the companies went through ownership changes and different generational successions. To understand the influence that these changes had on crafting new products, we analyzed the strategies that B\&B Italia and Cassina SpA adopted by studying how they differently managed tradition over the evolution of control and generations. Our aim was to shed light on the innovation through tradition model and contribute to the design literature by framing strategies to leverage product heritage in future designs. Thus, we ran two t-test analyses to measure design tradition intensity and design tradition depth. Calculating both indicators on an annual basis, we compared time periods characterized by different governance systems (control and generation).

Table 3 presents the different values and the t-test analyses of the design tradition indicators (design tradition intensity and design tradition depth) according to family or fund ownership control. The average value of design tradition intensity in the 33 years characterized by family ownership was $10.55 \%$, while it grew to $21.20 \%$ in the 37 years characterized by fund ownership. Similarly, design tradition depth showed lower values in the years characterized by family ownership (8.69\% vs. $13.33 \%$ ). According to these results, a significant difference is 
found in the behaviors between family and fund ownership. In particular, in the process of creating innovation through tradition, the fund exploits a greater number of advantages in terms of recalling elements of the firm's history. Both the design tradition intensity and design tradition depth indicators show that the search and recombination process was largely adopted in the case of family ownership, while fund ownership tended to recall elements that had great influence in the company's history by reusing elements from the past with greater seniority.

(Insert Table 3 about here)

In Table 4, we present the different values of the indicators (design tradition intensity and design tradition depth) accordingly to the 2 nd and 3rd generation period. Even if in the years when the 2 nd generation was present in both companies, the design tradition indicators were lower compared to those years when the 3rd generation was present, there was no significant difference between these two periods. In other words, the behaviors of the different generations remained largely the same.

(Insert Table 4 about here)

\section{Discussion and Conclusions}

As previously mentioned, our research is grounded in the innovation management field, particularly in the stream that considers design as the main driver of innovation, offering however a number of implications into the knowledge management field. Indeed, our intention was to explore how traditional and old knowledge participates in new product development, hence contributing to explain the strategic role played by knowledge maturity (e.g., Kruger and Johnson, 2010; Capaldo et al., 2017; Marques et al., 2019). We focused on a specific type of firm (family business), since these are the most likely to value tradition in the innovation process. We observed that these firms alternated phases of family and non-family control. However, how family firms manage innovation through tradition has scarcely been 
investigated, or how different ownership profiles influence this process. We analyzed designintensive firms where design is not a complementary element but the focus of their activities.

Our study responds to the need to find a way to measure the use of tradition in product design. We contribute to the design literature by providing evidence of commonalities identifiable in products (Dell'Era et al., 2008; Ravasi and Stigliani, 2012), rather than in the design collaboration network, and to the family business literature (Miller et al., 2008; Magistretti et al., 2019) by showing the influence that different ownership types can have on innovation through tradition.

The two indicators (design tradition intensity and design tradition depth) we propose contribute to the literature in several ways. First, devising a way to measure and quantify how designintensive firms use knowledge from the past on both the weight and the seniority aspects allows shedding new light on the product signs dimension of the overall innovation through tradition model (De Massis, et al., 2016a; Capaldo et al., 2017; Ardito et al., 2018; Presenza et al., 2019). Second, our study shows these two indicators are influenced by changes in ownership control. More specifically, in the periods when the fund was the main shareholder, the companies launched more design tradition products on the market and recalled historical elements of the past. Third, we offer novel insights to the knowledge management literature, by unveiling how firms can capture the extent to which old and traditional knowledge is managed and exploited to generate novel commercial offers (e.g., McKenzie et al., 2011; Oliva, 2014).

Moreover, a relevant theoretical contribution is in showing that the ways in which companies can leverage tradition are related to the intensity and depth of the product dimensions. This shift from the traditional study of designers (Cautela et al., 2018; Magistretti et al., 2019) to products is particularly interesting for the design literature. Indeed, the two indicators proposed illustrate how companies can achieve innovation through tradition, and that they can leverage 
knowledge from the past incorporated in the codified dimension of product signs (Benezech et al., 2001). In addition to this, the research contributes to the design knowledge discussion. Indeed, it shows how the product and process dimensions also the intensity and depth of the tradition leveraged to create new products is crucial in the product dimension of design knowledge (Åman, Andersson and Hobday, 2017). Building on design knowledge the paper also contributes to the literature on knowledge management and especially on knowledge creation, by identifying two indicators that might support the creative process crucial part of the design process especially of connected with knowledge creation (Simon, 2019).

Finally, the paper contributes to the family business literature (De Massis et al., 2016b) by showing that the innovation through tradition model is influenced by whether ownership is family or non-family controlled. This is of primary importance for this field that continually seeks knowledge on the difference that the ownership dimension might have on innovation strategies (Sasaki et al., 2019). Therefore, we reveal how the management of traditional and old knowledge significantly differs between family and non-family firms. Indeed, our findings show that family firms seem to be in a better position to manage old knowledge, since their conservative nature allows to establish tight and long-lasting links with tradition that make these firms more able to store, retrieve, and exploit past knowledge resources to innovate (e.g., Casprini et al., 2017; Chaudhary and Batra, 2018; Manfredi Latilla et al., 2019).

From a managerial viewpoint, we encourage managers to consider tradition and old knowledge as a potential source of innovation. In fact, tradition should not be regarded as inertia for innovation, but rather as an opportunity. Tradition plays a fundamental role in the process of creating innovation. In particular, recombining old knowledge and elements is a strategy to bring to the present the underpinning pillars of the firm itself. In addition, tradition can be leveraged and measured with the two proposed intensity and depth dimensions in relation to product signs. This may support managers in adopting the two different strategies for 
innovation through tradition. Moreover, we found that ownership control significantly influences innovation that leverages tradition. In particular, depending on whether the main shareholder is the family or a fund, intensity changes significantly. If the owner is a fund, the percentage of design tradition products over those launched every year on the market is higher than in the case of family ownership. In fact, it would seem that to underline the firm's values and vision, funds search for elements of the past that highlight the firm's history and provide continuity to its name. Instead, the presence of the family in the firm is enough to recall the name and the fundamental elements of the firm's history. Finally, when the fund is the main shareholder, the seniority of products recalled significantly changes. During fund ownership, managers tend to use elements that contributed to the firm's history, elements from iconic products anchored in the firm's roots that have a higher influence on customers, recalling tradition to simplify the brand recognition process.

Of course, our study has some limitations that open the way for future research. First, we have analyzed the impact of the different governance variables on the use of traditional elements from the past by conducting two case studies of companies in the same sector. In addition, although the companies we studied are well known internationally and are global leaders in the furniture industry, they belong to the same geographic area. Future research might validate our findings by investigating other companies in the furniture sector and in different geographic areas, or extending the analysis to different sectors. Using the two indicators proposed to analyze different markets might lead to valuable knowledge on innovation through tradition in family business. Notwithstanding this, the case study and the contributions reported above, even if they cannot be generalized, can inform academics in performing new researches in this field trying to solving the open issue related to the interplay between design, innovation, and knowledge management. 


\section{References}

Åman, P., Andersson, H., \& Hobday, M. (2017). The Scope of Design Knowledge: Integrating the Technically Rational and Human-Centered Dimensions. Design Issues, 33(2), 58-69.

Ardito, L., D'Adda, D. and Petruzzelli, A.M. (2018), "Mapping innovation dynamics in the Internet of Things domain: Evidence from patent analysis", Technological Forecasting and Social Change, Vol. 136, pp. 317-330.

Benezech, D., Lambert, G., Lanoux, B., Lerch, C. and Loos-Barion, J. (2001), “Completion of knowledge codification: An illustration through the ISO 9000 standards implementation process", Research Policy, Vol. 30 No. 9, pp. 1395-1407.

Beverland, M.B. (2005), "Crafting brand authenticity: The case of luxury wines", Journal of Management Studies, Vol. 42 No. 5, pp. 1003-1029.

Boland, R.J. and F. Collopy. (2004), Managing as Designing. Stanford University Press.

Borja de Mozota, B. (2004), Design Management: Using Design to Build Brand Value. Allworth Press Borja.

Brode, L., Dell'Era, C. and Verganti, R. (2014), "The contributions of interpreters to the development of radical innovations of meanings: The role of "pioneering projects" in the sustainable buildings industry", $R \& D$ Management, Vol. 44 No. 1, pp. 1-17.

Brown, T. (2008), “Design thinking”. Harvard Business Review, Vol. 86 No. 6, pp. 84-95.

Capaldo, A. (2007), "Network structure and innovation: The leveraging of a dual network as a distinctive relational capability", Strategic Management Journal, Vol. 28 No. 6, pp. 585608.

Capaldo, A., Lavie, D. and Messeni Petruzzelli, A.M. (2017), "Knowledge maturity and the scientific value of innovations: The roles of knowledge distance and adoption", Journal of Management, Vol. 43, pp. 503-533.

Cappetta, R., Cillo, P. and Ponti, A. (2006), "Convergent designs in fine fashion: An evolutionary model for stylistic innovation”, Research Policy, Vol. 35 No. 9, pp. 12731290.

Carrillo, J. (1997), "Managing knowledge-based value systems", Journal of Knowledge Management, Vol. 1 No. 4, pp. 280-286.

Casprini, E., De Massis, A., Di Minin, A., Frattini, F., \& Piccaluga, A. (2017). How family firms execute open innovation strategies: the Loccioni case. Journal of Knowledge Management, 21(6), 1459-1485.

Cautela, C., Simoni, M. and Zurlo, F. (2018), "New wine in old bottles or new bottles for new wine? Product language approaches in design-intensive industries during technological turmoil”, Creativity and Innovation Management, Vol. 27 No. 2, pp. 133-147.

Chaudhary, S., \& Batra, S. (2018). Absorptive capacity and small family firm performance: exploring the mediation processes. Journal of knowledge management, 22(6), 1201-1216.

Chrisman, J.J., Chua, J.H., De Massis, A., Frattini, F. and Wright, M. (2015), "The ability and willingness paradox in family firm innovation", Journal of Product Innovation Management, Vol. 32 No. 3, pp. 310-318.

Crane, L. (2012), "Trust me, I'm an expert: Identity construction and knowledge sharing", Journal of Knowledge Management, Vol. 16 No. 3, pp. 448-460.

Leonard-Barton, Sensiper, (1998). The role of tacit knowledge in group innovation, California Management Review $40 \quad 3$ 112-131 
Dalpiaz, E., Rindova, V. P., \& Ravasi, D. (2010). Where strategy meets culture: The neglected role of cultural and symbolic resources in strategy research. In The Globalization of Strategy Research (pp. 175-208). Emerald Group Publishing Limited.

De Massis, A., Chua, J.H. and Chrisman, J.J. (2008), "Factors preventing intra-family succession", Family Business Review, Vol. 21 No. 2, pp. 183-199.

De Massis, A., Frattini, F., Messeni Petruzzelli, A., Kotlar, J. and Wright, M. (2016a), "Innovation through tradition: Lessons from innovative family businesses and directions for future research", Academy of Management Perspectives, Vol. 30, pp. 93-116.

De Massis, A., Kotlar, J., Frattini, F., Chrisman, J.J. and Nordqvist, M. (2016b), "Family governance at work: Organizing for new product development in family SMEs", Family Business Review, Vol. 29 No. 2, pp. 189-213.

Dell'Era, C. and Verganti, R. (2010), "Collaborative strategies in design-intensive industries: knowledge diversity and innovation", Long Range Planning, Vol. 43 No. 1, pp. 123-141.

Dell'Era, C., Marchesi, A., \& Verganti, R. (2008). Linguistic Network Configurations: Management of innovation in design-intensive firms. International Journal of Innovation Management, 12(01), 1-19.

Dell'Era, C. and Verganti, R. (2007), "Strategies of innovation and imitation of product languages", Journal of Product Innovation Management, Vol. 24, pp. 580-599.

Dell'Era, C. and Verganti, R. (2011), "Diffusion processes of product meanings in designintensive industries: Determinants and dynamics", Journal of Product Innovation Management, Vol. 28 No. 6, pp. 881-895.

Dell'Era, C., Magistretti, S. and Verganti, R. (2018), "Exploring collaborative practices between SMEs and designers in the Italian furniture industry", Researching Open Innovation in SMEs, pp. 307-345.

Dumaine, B. (1991), "The bureaucracy busters", Fortune, Vol. 17, pp. 36-50.

Gasparin, M. and Green, W. (2018), "Reconstructing meaning without redesigning products: The case of the Serie7 chair", Creativity and Innovation Management, Vol. 27 No. 4, pp. 401-413.

Gurteen, D. (1998), "Knowledge, creativity and innovation", Journal of Knowledge Management, Vol. 2 No. 1, pp. 5-13.

Hibbert, P., \& Huxham, C. (2011). The carriage of tradition: Knowledge and its past in network contexts. Management Learning, 42(1), 7-24

Jeffery, R. (2005). Tradition as Invention: TheTraditions Tradition'and the History of Ideas in International Relations. Millennium, 34(1), 57-84.

Kammerlander, N., Dessi, C., Bird, M., Floris, M. and Murru, A. (2015), "The impact of shared stories on family firm innovation: A multicase study", Family Business Review, 28(4), Vol. 28 No. 4, pp. 332-354.

Karjalainen, T.M. and Snelders, D. (2010), "Designing visual recognition for the brand", Journal of Product Innovation Management, Vol. 27 No. 1, pp. 6-22.

Keen, P. and Tan, M. (2007), "Knowledge fusion: A framework for extending the rigor and relevance of knowledge management", International Journal of Knowledge Management, Vol. 3 No. 4, pp. 1-17.

Kelley, T. (2001), The Art of Innovation: Lessons in Creativity from IDEO, America's Leading Design Firm. London: Harper Collins Business.

Kruger, C. J., \& Johnson, R. D. (2010). Principles in knowledge management maturity: a South African perspective. Journal of Knowledge Management, 14(4), 540-556. 
Leonard-Barton, D. (1992), "Core capabilities and core rigidities: A paradox in managing new product development", Strategic Management Journal, Vol. 13, pp. 111-125.

Lojacono, G. and Zaccai, G. (2004), "The evolution of the design-inspired enterprise", MIT Sloan Management Review, Vol. 45 No. 3, pp. 75-79.

Magistretti, S. and Dell'Era, C. (2019), "Unveiling opportunities afforded by emerging technologies: Evidences from the drone industry", Technology Analysis \& Strategic Management, Vol. 31 No. 4, pp. 606-623.

Magistretti, S., Dell'Era, C., De Massis, A. and Frattini, F. (2019), "Exploring the relationship between types of family involvement and collaborative innovation in design-intensive firms: Insights from two leading players in the furniture industry", Industry and Innovation, Vol. 26 No. 10, pp. 1-31.

Manfredi Latilla, V., Frattini, F., Messeni Petruzzelli, A. and Berner, M. (2019), "Knowledge management, knowledge transfer and organizational performance in the arts and crafts industry: A literature review", Journal of Knowledge Management, Vol. 22 No. 6, pp. 13101331.

Marques, J. M. R., La Falce, J. L., Marques, F. M. F. R., De Muylder, C. F., \& Silva, J. T. M. (2019). The relationship between organizational commitment, knowledge transfer and knowledge management maturity. Journal of Knowledge Management, 23(3), 489-507.

McCormack, J.P. and Cagan, J. (2004), "Speaking the Buick language: Capturing, understanding, and exploring brand identity with shape grammars", Design Studies, Vol. 25 No. 1, pp. 1-29.

McKenzie, J., van Winkelen, C., \& Grewal, S. (2011). Developing organisational decisionmaking capability: a knowledge manager's guide. Journal of Knowledge Management, 15(3), 403-421.

Messeni Petruzzelli, A., and Savino, T. (2015), "Reinterpreting tradition to innovate: The case of the Italian haute cuisine", Industry and Innovation, Vol. 22, pp. 677-702.

Messeni Petruzzelli, A., Rotolo, D. and Albino, V. (2012), "The impact of old technologies on innovation. The case of the US biotechnology industry", Technology Analysis \& Strategic Management, Vol. 24, pp. 453-466.

Micheli, P. and Gemser, G. (2016), "Signaling strategies for innovative design: A study on design tradition and expert attention", Journal of Product Innovation Management, Vol. 33 No. 5, pp. 613-627.

Miller, D., Le Breton-Miller, I., \& Lester, R. H. (2010). Family ownership and acquisition behavior in publicly-traded companies. Strategic Management Journal, 31(2), 201-223.

Oliva, F. L. (2014). Knowledge management barriers, practices and maturity model. Journal of Knowledge Management.

Pesendorfer, W. (1995), "Design innovation and fashion cycles", The American Economic Review, pp. 771-792.

Platt, M.B., Hertenstein, J.N., David, R.B. (2001), "Valuing design: Enhancing corporate performance through design effectiveness", Design Management Journal, Vol. 12 No. 3, pp. 10-19.

Postrel, V. (2003), The Substance of Style: How the Rise of Aesthetic Value is Remaking Culture, Commerce, and Consciousness. Harper Collins. New York.

Presenza, A., Messeni Petruzzelli, A. and Sheehan, L. (2019), "Innovation through tradition in hospitality. The Italian case of Albergo Diffuso", Tourism Management, Vol. 72, pp. 192201. 
Ravasi, D. and Lojacono, G. (2005), "Managing design and designers for strategic renewal", Long Range Planning, Vol. 38 No. 1, pp. 51-77.

Ravasi, D. and Stigliani, I. (2012), "Product design: A review and research agenda for management studies", International Journal of Management Reviews, Vol. 214 No. 4, pp. 464-488.

Sasaki, I., Kotlar, J., Ravasi, D. and Vaara, E. (2019), "Dealing with revered past: Historical identity statements and strategic change in Japanese family firms", Strategic Management Journal, doi.org/10.1002/smj.3065.

Schmitt, B. and Simonson, A. (1997), Marketing Aesthetics: The Strategic Management of Brands, Identity, and Image. New York: Free Press.

Siggelkow, N. (2007), "Persuasion with case studies", Academy of Management Journal, Vol. 50 No. 1, pp. 20-24.

Simeone, L., Secundo, G., \& Schiuma, G. (2017). Knowledge translation mechanisms in open innovation: the role of design in R\&D projects. Journal of Knowledge Management, 21(6), 1406-1429.

Simon, H. A. (2019). The sciences of the artificial. MIT press.

Simoni, M., Cautela, C. and Zurlo, F. (2019), "Designer portfolio archetypes in designintensive industries", Industry and Innovation, Vol. 26 No. 10, pp. 1-34.

Sørensen, J. and Stuart, T. (2000), “Aging, obsolescence, and organizational innovation", Administrative Science Quarterly, Vol. 45 No. 2, pp. 81-112.

Stompff, G. (2003), "The forgotten bond: Brand identity and product design", Design Management Journal, Vol. 14 No. 1, pp. 26-32.

Swan, J., Newell, S., Scarbrough, H. and Hislop, D. (1999), "Knowledge management and innovation: networks and networking", Journal of Knowledge Management, Vol. 3 No. 42, pp. 262-275.

Tiwana, A., \& Ramesh, B. (2001). A design knowledge management system to support collaborative information product evolution. Decision Support Systems, 31(2), 241-262.

Trabucchi, D., Pellizzoni, E., Buganza, T. and Verganti, R. (2017), "Interplay between technology and meaning: How music majors reacted?" Creativity and Innovation Management, Vol. 26 No. 4, pp. 327-338.

Verganti, R. (2009), Design-Driven Innovation. Changing the Rules of Competition by Radically Innovating What Things Mean. Boston: Harvard Business Press.

Veryzer, R.W. (2005), "The roles of marketing and industrial design in discontinuous new product development", Journal of Product Innovation Management, Vol. 22 No. 1, pp. 2241.

Walsh, V. (1996), "Design, innovation and the boundaries of the firm", Research Policy, Vol. 25 No. 4, pp. 509-529.

Yin, R. K. (2011), Applications of Case Study Research. Sage.

Zha, X. F., \& Sriram, R. D. (2006). Platform-based product design and development: A knowledge-intensive support approach. Knowledge-Based Systems, 19(7), 524-543.

\section{FIGURES}




\begin{tabular}{|c|c|c|c|c|}
\hline $\begin{array}{l}\text { SOURCES OF PAST } \\
\text { KNOWLEDGE }\end{array}$ & ITT CAPABILITY & $\begin{array}{l}\text { FORMS OF PAST } \\
\text { KNOWLEDGE }\end{array}$ & ITT CAPABILITY & $\begin{array}{c}\text { PRODUCT } \\
\text { INNOVATION }\end{array}$ \\
\hline
\end{tabular}

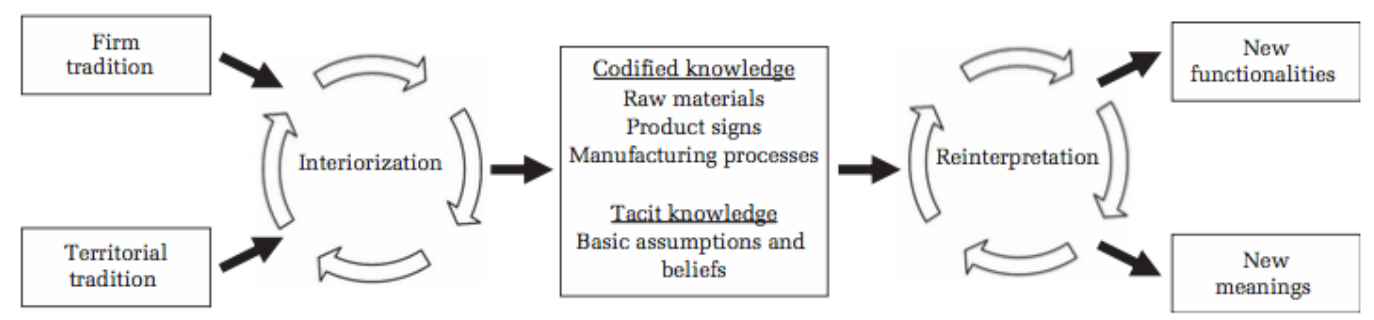

Figure 1: Innovation Through Tradition model (De Massis et al., 2016).

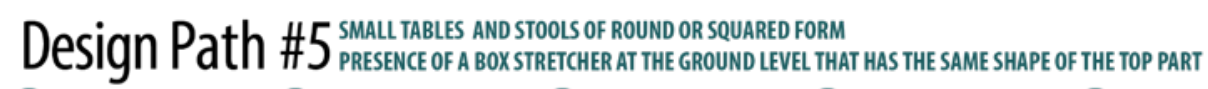

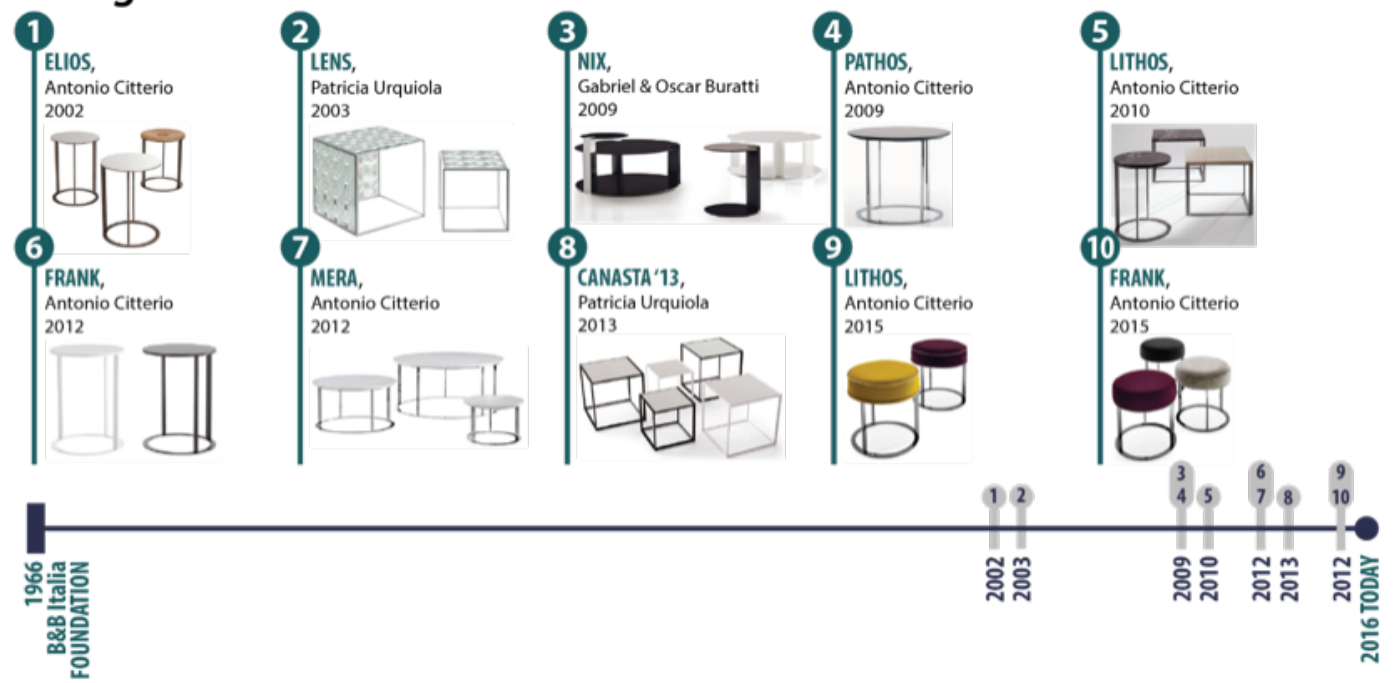

Figure 2: Example of design path.

CONTROL

Family

Fund

1966

2003

GENERATION

$1 s t$

2nd

$3 r d$

Figure 3: Control and Generation changes in B\&B Italia. 


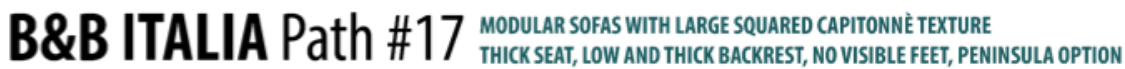

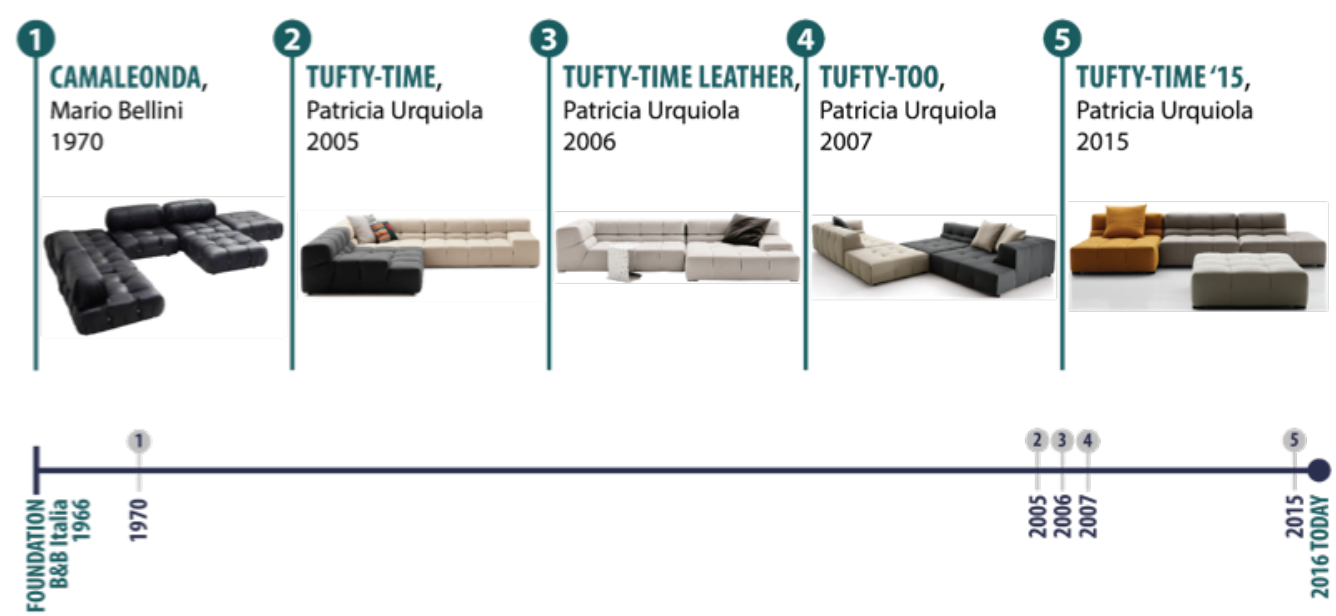

Figure 4: Example of design path in B\&B Italia.

CONTROL

\section{GENERATION}

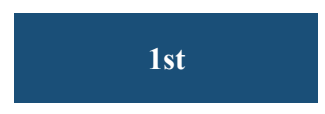

1974

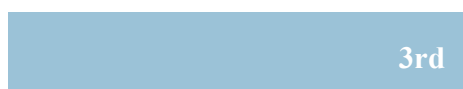

1989

Figure 5: Control and Generation changes in Cassina SpA.

\section{Design Path \#14}
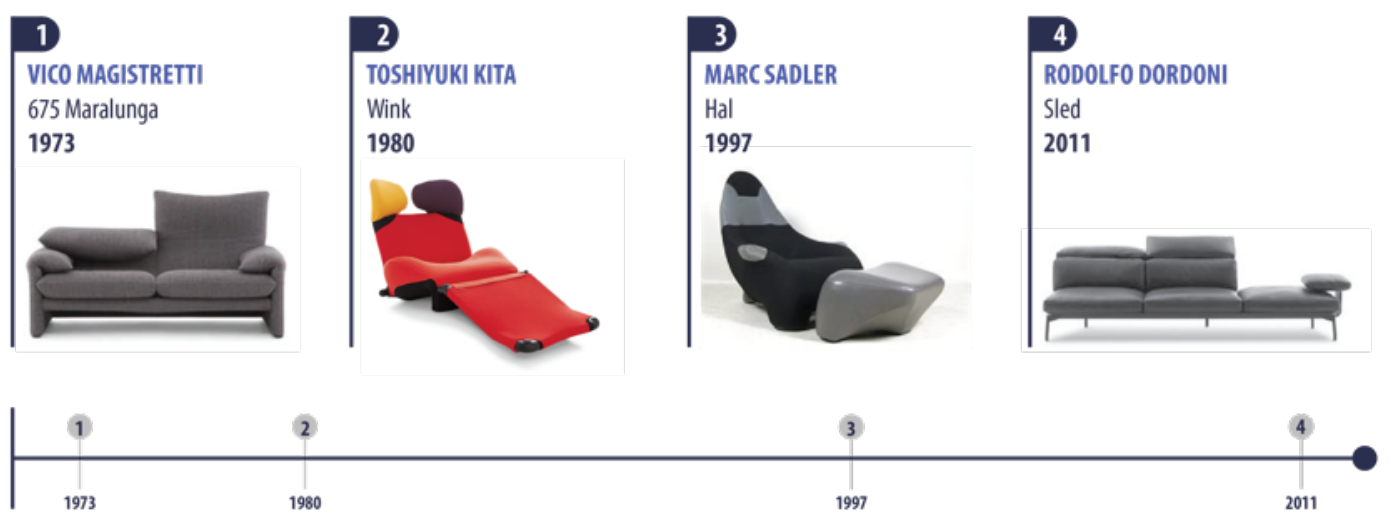

Figure 6: Example of design path in Cassina SpA 


\section{TABLES}

Table 1: Case Studies Overview

\begin{tabular}{|c|c|c|}
\hline Company & $\begin{array}{l}\text { Year of } \\
\text { Foundation }\end{array}$ & Description of the Company \\
\hline B\&B Italia & 1966 & $\begin{array}{l}\text { B\&B Italia is a leading Italian furniture company that takes its origin } \\
\text { from the C\&B Italia firm founded in } 1966 \text { by Piero Ambrogio Busnelli } \\
\text { and Cesare Cassina. Presently, B\&B Italia is well known for its high } \\
\text { quality design products in the domestic sector (B\&B Italia domestic } \\
\text { division) and in the contract sector (B\&B Italia contract division). Since } \\
\text { its founding, the firm has been devoted to innovation. Since 1973, the } \\
\text { Busnelli family has controlled the firm, but starting in } 2003 \text { two different } \\
\text { private equity funds acquired the stocks of the company. Initially Opera } \\
\text { and in later stages Investindustrial. B\&B Italia is a design-intensive firm } \\
\text { that has cooperated during its existence with many successful designers } \\
\text { to produce and commercialize over hundreds of products. B\&B Italia is } \\
\text { a managerial firm and currently sees the participation in the management } \\
\text { of both the second generation and the third generation of the family. }\end{array}$ \\
\hline Cassina SpA & 1927 & $\begin{array}{l}\text { Cassina, founded as "Figli di Amedeo Cassina" by Cesare and Cesare } \\
\text { Cassina in 1927, is a leading furniture firm of Italian design. In 1935, } \\
\text { the two sons of Amedeo changed the name to "Figli di Amedeo } \\
\text { Cassina." The firm's headquarters are situated in Meda (Italy). Cassina } \\
\text { started its process of internationalization during its early stages, } \\
\text { starting in } 1973 \text { with the arrival of Rodrigo Rodriquez as general } \\
\text { manager. Thanks to his managerial experience and knowledge, Dr. } \\
\text { Rodriquez changed the firm in terms of managerial and new product } \\
\text { development approaches. It was in this era that the legendary collection } \\
\text { "I grandi maestri" was created. The Cassina family owned and } \\
\text { managed the firm up to 1989. In the following years, the ownership } \\
\text { changed frequently: In 1989, a French investor named Strafor Facom } \\
\text { bought } 50 \% \text { of Cassina's stocks. Moreover, in } 2005 \text {, Cassina holdings } \\
\text { in SpA sold the } 80 \% \text { of its stock to Charme Investments and entered in } \\
\text { the Poltrona Frau Group. Finally, in 2014, a leading American furniture } \\
\text { firm, Haworth, bought the firm. }\end{array}$ \\
\hline
\end{tabular}

Table 2: B\&B Italia and Cassina SpA Interviews

\section{Company}

B\&B Italia

Cassina SpA

\section{Job Position}

R\&D Director

Director B\&B USA

Industrial Director

General Manager

Global Comm. Director

CEO Private Equity Fund 2008-2011

(Opera Sgr)

\section{Director}

Director R\&D

Archivist
Years

1973-2016

2000-2006

1999-2011

1987-2011

1983-2015

1972-1991

1989-2006

1999-2015

\section{Interview Date}

$05 / 05 / 2015$

$05 / 14 / 2015$

$01 / 22 / 2015$

$02 / 05 / 2015$

$05 / 05 / 2015$

03/30/2015

$02 / 03 / 2015$

$05 / 25 / 2015$

$03 / 20 / 2015$ 
Table 3: T-test about Control $\left({ }^{*} p<.05 ; * * p<.01\right)$

\begin{tabular}{l|c|c|c|c}
\multirow{2}{*}{} & \multicolumn{2}{|c|}{$\begin{array}{r}\text { DESIGN TRADITION } \\
\text { INTENSITY }\end{array}$} & \multicolumn{2}{c}{$\begin{array}{r}\text { DESIGN TRADITION } \\
\text { DEPTH }\end{array}$} \\
\hline \multirow{2}{*}{$\begin{array}{l}\text { Family owner } \\
\text { Fund owner }\end{array}$} & $10.55 \%$ & 33 & 8.69 & 14 \\
\cline { 2 - 5 } & $21.20 \%$ & 37 & 13.33 & 28 \\
\hline P-Value & \multicolumn{2}{|c|}{$\mathbf{0 . 0 0 9 3 * *}^{* *}$} & \multicolumn{2}{c}{$0.0282^{*}$}
\end{tabular}

T-test for $\mu$ Family $\neq \mu$ Fund $\alpha=0.05$

Table 4: $T$-test about Generation $\left({ }^{*} p<.05 ;{ }^{*} p<.01\right)$

\begin{tabular}{l|c|c|c|c}
\multirow{2}{*}{} & \multicolumn{2}{|c|}{$\begin{array}{r}\text { DESIGN TRADITION } \\
\text { INTENSITY }\end{array}$} & \multicolumn{2}{c}{$\begin{array}{r}\text { DESIGN TRADITION } \\
\text { DEPTH }\end{array}$} \\
\hline \multirow{2}{*}{$2^{\circ}$ Generation } & $14.07 \%$ & 39 & 7.83 & 20 \\
\cline { 2 - 5 } & Average & $\#$ & Average & 12 \\
\cline { 2 - 5 } $3^{\circ}$ Generation & $17.03 \%$ & 20 & 10.68 & 12 \\
\hline P-Value & \multicolumn{2}{|c|}{0.5561} & 0.1495
\end{tabular}

T-test for $\mu 2^{\circ} \mathrm{Gen} \neq \mu 3^{\circ} \mathrm{Gen}$ $\alpha=0.05$ 